\title{
Rapid start-up of anammox reactor using granular sludge supported on activated carbon
}

\author{
Liu X.1,2, Wang D. ${ }^{2}$, and Zhang W. ${ }^{3 *}$ \\ ${ }^{1}$ Guangxi Key Laboratory of Theory \& Technology for Environmental Pollution Control, College of Environmental Science and Engineering, \\ Guilin University of Technology, 12 Jiangan Road, Qixing District, Guilin, China \\ ${ }^{2}$ Guangxi Collaborative Innovation Center for Water Pollution Control and Water Safety in Karst Area, Guilin University of Technology, \\ 12 Jiangan Road, Qixing District, Guilin, China \\ ${ }^{3}$ College of Environmental Science and Engineering, Guilin University of Technology, 12 Jiangan Road, Qixing District, Guilin, China \\ Received: 29/07/2020, Accepted: 13/09/2020, Available online: 18/09/2020 \\ *to whom all correspondence should be addressed: e-mail: 2010053@glut.edu.cn
} https://doi.org/10.30955/gnj.003426

\section{Graphical abstract}

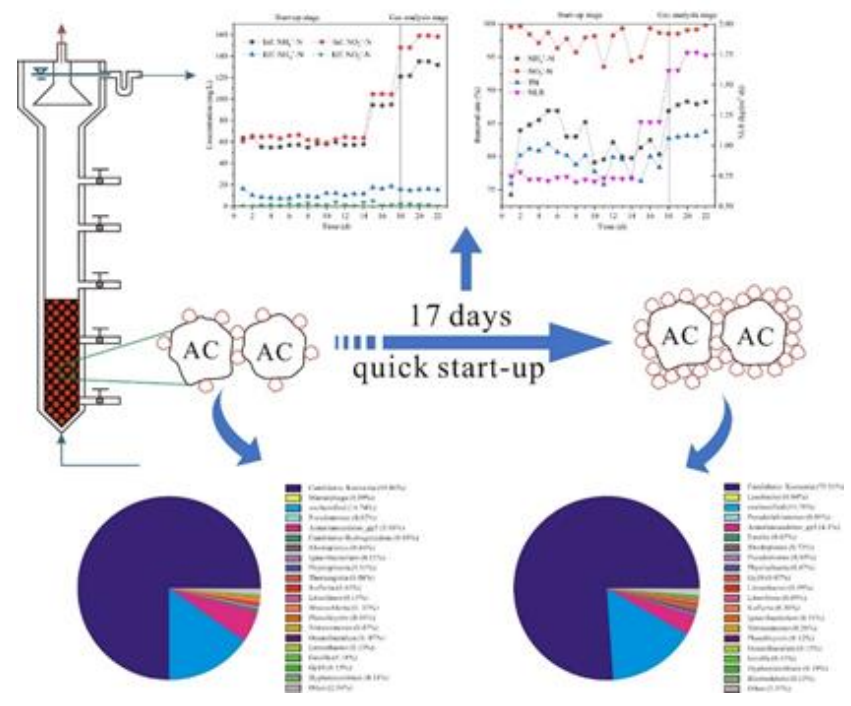

\section{Abstract}

The long start-up time and high demand of anaerobic ammonium oxidation (anammox) limit the practical applications of the anammox process. In this study, granular sludge supported on activated carbon (AC) was used as seed sludge. The start-up time of the reactor was substantially shortened, and the expanded granular sludge bed (EGSB) reactor could be started quickly (in only 17 days). The nitrogen load rate (NLR) increased from $0.61 \mathrm{~kg}$ $\mathrm{m}^{-3} \mathrm{~d}^{-1}$ to $1.19 \mathrm{~kg} \mathrm{~m}^{-3} \mathrm{~d}^{-1}$, the removal rate of total nitrogen (TN) increased from $78.04 \%$ to83.15\%, and the final ratio $\mathrm{NH}_{4}{ }^{+}: \mathrm{NO}_{2}{ }^{-}: \mathrm{NO}_{3}{ }^{-}$was $1: 1.33: 0.30$. Moreover, in the gas analysis phase, the reactor load could be further improved and increased to $1.70 \mathrm{~kg} \mathrm{~m}^{-3} \mathrm{~d}^{-1}$ from the $18^{\text {th }}-22^{\text {nd }}$ day, and the reactor run stably. During this period, $\mathrm{N}_{2} \mathrm{O}$ and $\mathrm{CO}_{2}$ production was $0.8 \%$ and $0.02 \%$, respectively. According to the analysis of microorganisms, the main functional microorganism in the reactor was Candidatus Kuenenia. The content of Candidatus Kuenenia increased by $5.45 \%$ after the reactor was started successfully. The color of sludge was brick red. This showed that the operation mode and inoculated sludge employed in this study are highly effective for the fast start-up of an EGSB reactor.

Keywords: Activated carbon, anaerobic ammonium oxidation, nitrogen removal, EGSB reactor.

\section{Introduction}

Under anoxic conditions, anaerobic ammonium oxidation (anammox) bacteria can convert $\mathrm{NH}_{4}{ }^{+}$into $\mathrm{N}_{2}$ by taking $\mathrm{NO}_{2}{ }^{-}$as an electron acceptor and $\mathrm{NO}_{3}{ }^{-}$(approximately $11 \%$ of total nitrogen) as the by-product (Mulder et al., 1995). Compared with traditional nitrification and denitrification, anammox has many advantages, such as no aeration, no organic carbon, high nitrogen removal efficiency, and low sludge yield. These advantages can save energy consumption and reduce operation costs. Anammox is considered to be the most promising application in wastewater treatment, with a high nitrogen concentration and low carbon nitrogen ratio (Wang et al., 2018). The biological reaction of anammox can be described as follows (Jetten et al., 1998):

$$
\begin{aligned}
& \mathrm{NH}_{4}{ }^{+}+1.32 \mathrm{NO}_{2}^{-}+0.066 \mathrm{HCO}_{3}^{-}+0.13 \mathrm{H} \rightarrow 1.02 \mathrm{~N}_{2}+ \\
& 0.256 \mathrm{NO}_{3}{ }^{-}+0.066 \mathrm{H}_{2} \mathrm{O}_{0.5} \mathrm{~N}_{0.15}+2.03 \mathrm{H}_{2} \mathrm{O}
\end{aligned}
$$

Due to the long generation cycle of anammox (approximately $10^{-1} 4$ days at $30-40{ }^{\circ} \mathrm{C}$ ) (Strous M. et al., 1998), it is sensitive to environmental factors and has a long start-up time. Therefore, the anammox process has been greatly limited in the practical application process (Wen et al., 2020). Therefore, the effective enrichment and retention of anammox bacteria are necessary to ensure the stable operation of the process and to improve the efficiency of nitrogen removal. Previous studies have confirmed that the start-up time of the anammox process is related to the inoculum. For example, Tomar et al. (2015) inoculated mixed seed culture (anoxic and activated sludge) in an improved anammox hybrid reactor, which 
significantly shortened the start-up time and improved nitrogen removal efficiency. Tang et al. (2013) proposed a novel mixed inoculation method. They used two up-flow anaerobic sludge bed (UASB) reactors to start the anammox process via the mixed inoculation of anaerobic granular sludge and nitrified sludge. It took less time to start the anammox process than when using anaerobic granular sludge. Therefore, it was found that the start-up of an anammox reactor could be accelerated by the appropriate inoculation method.

Compared with ordinary activated sludge, granular sludge has a compact structure and good settling performance and impact load resistance. It can maintain a large amount of biomass and has a good effect on wastewater treatment. The cultivation of anammox granular sludge is more conducive to the enrichment and maintenance of anammox bacteria, which is an important form to ensure good nitrogen removal performance. At present, scholars have performed substantial research on the formation mechanism and rapid start-up of anammox granular sludge (Liu et al., 2020). The formation of anammox granular sludge has excellent biomass retention and sedimentation performance and greatly improves the ability of withstand impact load. Under the condition of high cell density, the information exchange and cooperation between anammox bacteria is strengthened, which increases the metabolism and activity of bacteria (Strous M et al., 1999). However, anammox granular sludge is a complex microbial symbiosis system.

Different cultural conditions, such as flow shear force, substrate concentration, and nitrogen load, will lead to a difference in granular sludge. It also takes a long time to cultivate anammox bacteria in granular sludge to produce high activity. With a porous structure and high thermal stability, activated carbon (AC) can be used as an adsorbent, catalyst, or catalyst carrier for various industrial applications (such as wastewater treatment, discoloration, and recovery of chemicals) (Basta et al., 2019). AC is a good prospective candidate as the carrier of anammox granular sludge. Expanded granular sludge bed (EGSB) reactors and UASB reactors are widely used in the cultivation of anammox granular sludge (Jin P. et al., 2019; Liu et al., 2020). However, the structure, performance, and operation parameters of the two reactors are different. This will inevitably lead to differences in the characteristics of anammox granular sludge and the microbial community structure. Therefore, the type of reactor will affect the nitrogen removal performance of anammox.

In this study, we used an EGSB reactor to inoculate anammox granular sludge supported on $A C$ to study a method to start and stably operate the anammox reactor quickly. The nitrogen removal efficiency, morphological structure change, and microbial diversity of anammox granular sludge in the process of start-up were analyzed. The gas generation during the anammox process was analyzed to determine the optimal operation mode of the reactor start-up.

\section{Materials and methods}

\subsection{Experimental setup}

The experimental equipment used was an EGSB reactor. The main body of the reactor is made of plexiglass, the height is $120 \mathrm{~cm}$, the inner diameter is $14 \mathrm{~cm}$, and the effective volume is $10 \mathrm{~L}$. The experimental setup is shown in Figure 1. The reactor is equipped with a thermalinsulation interlayer, and the temperature control system continuously provides thermal insulation by circulating water around the reactor, thereby maintaining its temperature at $33 \pm 1{ }^{\circ} \mathrm{C}$. The reactor was wrapped with thick black cloth to prevent the influence of light on anammox. The influent water was continuously pumped from the bottom of the reactor by a peristaltic pump (BT 00-100M Baoding Lange constant flow pump Co., Ltd.) and then discharged from the upper region after reaction by the sludge bed in the reactor. A three-phase separator was arranged at the top of the reactor to prevent the sludge from traveling along with the water flow. The gas produced in the reaction process was collected by the gas gathering system after passing through the three-phase separator. Sludge samples in the reactor were collected from sampling port two. The water outlet was provided with a U-shaped groove for liquid sealing to prevent gas from escaping.

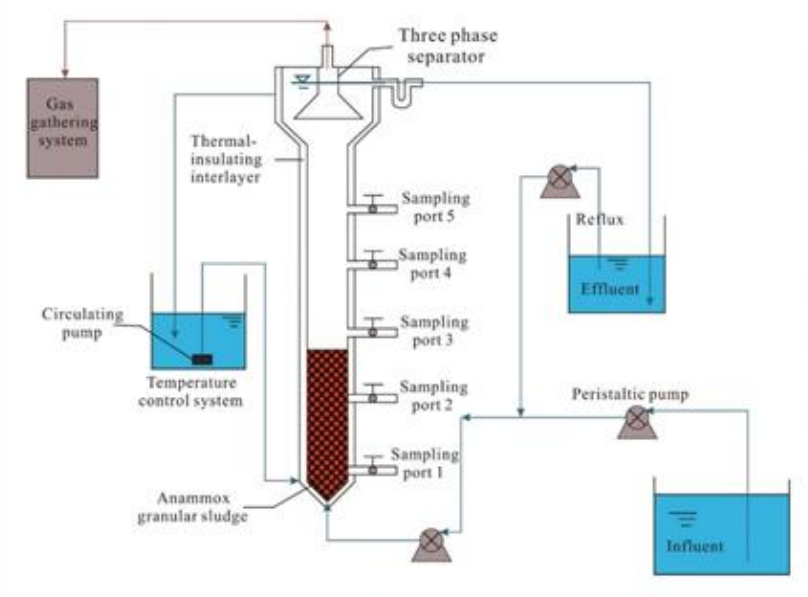

Figure 1. Schematic diagram of the experimental setup

\subsection{Test water and inoculated sludge}

Artificially simulated wastewater was used as the influent water for the test. The influent $\mathrm{NH}_{4}{ }^{+}-\mathrm{N}$ and $\mathrm{NO}_{2}{ }^{-}-\mathrm{N}$ were provided by $\mathrm{NH}_{4} \mathrm{HCO}_{3}$ and $\mathrm{NaNO}_{2}$, respectively. $\mathrm{KHCO}_{3}$ provided the carbon source for the anammox. $\mathrm{MgSO}_{4} \cdot 7 \mathrm{H}_{2} \mathrm{O}, \mathrm{Na}_{2} \mathrm{~S}_{2} \mathrm{O}_{3}, \mathrm{CaCl}_{2} \cdot 7 \mathrm{H}_{2} \mathrm{O}$, and microelements I and II provided various nutrients for the growth of the anammox. We use $99 \%$ high purity nitrogen aeration (the nitrogen is supplied by the nitrogen generator) to deoxidize the artificially prepared water. Finally, a small amount of anhydrous $\mathrm{Na}_{2} \mathrm{SO}_{3}$ was added to keep the dissolved oxygen (DO) concentration of the influent water below $0.10 \mathrm{mg} \mathrm{L}^{-1}$. The $\mathrm{pH}$ changes in the reactor were monitored by a realtime online monitor. The $\mathrm{pH}$ was adjusted to approximately 7.5. The concentration of $\mathrm{NO}_{2}^{-}-\mathrm{N}$ in the influent water was higher after the reactor activity was restored. To maintain 
the stable operation of the reactor in this experiment, external circulation was set up. External circulation can not only dilute the high concentration of $\mathrm{NO}_{2}{ }^{-}-\mathrm{N}$, but also make the reaction matrix form an internal circulation in the reactor and strengthen the mass transfer between the reaction matrix and the anammox microorganism. The mass transfer degree of different circulation flows and influent flows is also different, which makes the gas production rate and content of the reactor fluctuate. Therefore, the ratio of circulating to inflow flow was strictly controlled at 2:1. The composition of artificially simulated wastewater is shown in Table 1.

Anammox sludge was inoculated in the reactor, which was being cultivated by China-Japan membrane technology research center of the Guilin University of Technology. The anammox sludge is poured into the reactor after settling and pouring the supernatant. The inoculation amount accounted for $5 \%$ of the effective volume of the reactor. The VSS/SS value was 0.73 . During the start-up of the reactor, granular AC and anammox sludge were added for a mixed culture.

Table 1. Composition of artificial wastewater

\begin{tabular}{cccc}
\hline Component & Concentration (mg L & & Concentration (mg L \\
\hline $\mathrm{NH}_{4} \mathrm{HCO}_{3}, \mathrm{NaNO}_{2}$ & On demand preparation & $\mathrm{MgSO}_{4} .7 \mathrm{H}_{2} \mathrm{O}$ & 200 \\
\hline $\mathrm{KHCO}_{3}$ & 1500 & $\mathrm{Na}_{2} \mathrm{~S}_{2} \mathrm{O}_{3}$ & 24.81 \\
\hline $\mathrm{KH}_{2} \mathrm{PO}_{4}$ & On demand preparation & Microelements I & $1 \mathrm{~mL} \mathrm{~L}^{-1}$ \\
\hline $\mathrm{CaCl}_{2} .7 \mathrm{H}_{2} \mathrm{O}$ & 226.6 & Microelements II & $1 \mathrm{~mL} \mathrm{~L}^{-1}$ \\
\hline
\end{tabular}

${ }_{1}$ Microelements I composition (g L $\mathrm{L}^{-1}$ ): $\mathrm{FeSO}_{4} 7 \mathrm{H}_{2} \mathrm{O} 10 \mathrm{~g} \mathrm{~L}^{-1}, \mathrm{C}_{10} \mathrm{H}_{14} \mathrm{~N}_{2} \mathrm{Na}_{2} \mathrm{O}_{3} 5.6 \mathrm{~g} \mathrm{~L}^{-1}$

2 Microelements I/ composition ( $\mathrm{g} \mathrm{L}^{-1}$ ): $\mathrm{MnCl}_{2} \cdot 4 \mathrm{H}_{2} \mathrm{O} 0.352 \mathrm{~g} \mathrm{~L}^{-1}, \mathrm{CoCl}_{2} \cdot 6 \mathrm{H}_{2} \mathrm{O} 0.096 \mathrm{~g} \mathrm{~L}^{-1}, \mathrm{NiCl}_{2} \cdot 6 \mathrm{H}_{2} \mathrm{O} 0.08 \mathrm{~g} \mathrm{~L}^{-1}, \mathrm{CuSO}_{4} \cdot 5 \mathrm{H}_{2} \mathrm{O}_{0.1} \mathrm{~g} \mathrm{~L}^{-1}$, $\mathrm{ZnSO}_{4} \cdot 7 \mathrm{H}_{2} \mathrm{O} 0.172 \mathrm{~g} \mathrm{~L}^{-1}, \mathrm{NaSeO}_{4} \cdot 1 \mathrm{OH}_{2} \mathrm{O} 0.105 \mathrm{~g} \mathrm{~L}^{-1}, \mathrm{NaMoO}_{4} \cdot 2 \mathrm{H}_{2} \mathrm{O} 0.11 \mathrm{~g} \mathrm{~L}^{-1}, \mathrm{C}_{10} \mathrm{H}_{14} \mathrm{~N}_{2} \mathrm{Na}_{2} \mathrm{O}_{3} 5.0 \mathrm{~g} \mathrm{~L}^{-1}$

Table 2. Comparison of Anammox reactor start-up using different seed sludge

\begin{tabular}{|c|c|c|c|c|c|}
\hline Reactor types & Seed sludge & Operation time & HRT(h) & TN remove rate & References \\
\hline SNAD & $\begin{array}{c}\text { Anammox sludge } \\
\text { and nitrification } \\
\text { sludge }\end{array}$ & 75 & 6 & $85.4 \%$ & Miao et al. (2020) \\
\hline $\begin{array}{c}\text { ABR-Nitritation- } \\
\text { Anammox } \\
\end{array}$ & \multirow{2}{*}{$\begin{array}{c}\text { Laboratory } \\
\text { anammox reactor }\end{array}$} & 75 & 18 & $86-92 \%$ & \multirow[t]{2}{*}{ Wu et al. (2020) } \\
\hline ABR-CANON & & 101 & 3 & $81-87 \%$ & \\
\hline EGSB & $\begin{array}{l}\text { Long-starvation } \\
\text { Anammox sludge }\end{array}$ & 34 & 6 & $87.93 \%$ & Zhang et al. (2014) \\
\hline EGSB & $\begin{array}{l}\text { Anammox sludge } \\
\text { supported on AC }\end{array}$ & 17 & 4 & $83.15 \%$ & This study \\
\hline
\end{tabular}

\subsection{Analytical methods}

The effluent was collected from the reactor and put it into a sampling bottle for testing after passing through the 0.45 $\mu \mathrm{m}$ filter membrane. If not tested immediately, the effluent was stored in a refrigerator kept at $4{ }^{\circ} \mathrm{C}$ and tested as soon as possible. The anammox granular sludge was collected and placed in a $-20^{\circ} \mathrm{C}$ refrigerator for molecular biology experiments. The conventional water quality indexes determined in this test were: $\mathrm{NH}_{4}{ }^{+}-\mathrm{N}, \mathrm{NO}_{2}{ }^{-}-\mathrm{N}, \mathrm{NO}_{3}{ }^{-}-\mathrm{N}$, and TN. $\mathrm{NH}_{4}{ }^{+}-\mathrm{N}$ was determined by Nessler reagent spectrophotometry. $\mathrm{NO}_{2}{ }^{-}-\mathrm{N}$ was determined by $\mathrm{N}$-(1-nike)ethylenediamine spectro-photometry. TN was determined by basic potassium persulfate ultraviolet spectrophotometry. $\mathrm{NO}_{3}{ }^{-}-\mathrm{N}$ was calculated from the difference between $\mathrm{TN}$ and the sum of $\mathrm{NO}_{2}{ }^{-}-\mathrm{N}$ and $\mathrm{NH}_{4}{ }^{+}-\mathrm{N}$. $\mathrm{pH}$ and temperature were measured by an acidity meter (9010, Jenco model), and DO was measured by a portable DO meter (6010, Jenco model).

The gas was collected by a completely enclosed reaction device. A gas sampling bag was used to collect the gas from the exhaust valve at the top of the reactor and measure the gas production rate of the EGSB reactor (Liu et al., 2019). The content of $\mathrm{N}_{2} \mathrm{O}$ and $\mathrm{CO}_{2}$ in the gas samples was determined using a gas chromatograph (Shanghai Jingke,
GC-112A) with a thermal conductivity detector, the minimum detection limit was $1 \times 10^{-9} \mathrm{~g} / \mathrm{mL}$ ). The content of $\mathrm{N}_{2} \mathrm{O}$ and $\mathrm{CO}_{2}$ in the sample was calculated, and each gas sample was tested at least three times to obtain the average value.

\subsection{Sludge sample analysis}

The morphology of granular sludge was observed by scanning electron microscope (SEM). The pretreatment of sludge samples for SEM is as follows Zhang et al. (2015). First, the granular sludge was fixed in a $2.5 \%$ Glutaric dialdehyde solution $\left(\mathrm{C}_{5} \mathrm{H}_{8} \mathrm{O}_{2}, \mathrm{pH} 7.2\right.$, it can quickly pass through the plasma membrane and solidify the biological macromolecules in the cell), and placed at $4{ }^{\circ} \mathrm{C}$ overnight. The fixed solution was poured out, and the sample was rinsed three times with $0.1 \mathrm{~mol} / \mathrm{L}$ phosphate buffer $(\mathrm{pH} 7.2)$ for 15 min each time. Then, 30\%, 50\%, 70\%, 85\%, 95\%, and $100 \%$ ethanol were used for gradient dehydration; each concentration was rinsed three times for $15 \mathrm{~min}$. The samples were then dried at the carbon dioxide critical temperature. Non-conductive samples generate charge accumulation under the electron beam in the SEM. This affects the incident electron beam spot and the trajectory of secondary electrons, which reduces the quality of the picture. As granular sludge is a non-conductive sample, it was fixed on the sample table with conductive adhesive 
and observed after spraying with gold. Finally, the SEM (JSM-6380LV, JEOL, Tokyo) was used to take images of the prepared samples.

The sludge samples from the EGSB reactor at the end of operation were collected and stored at $-20^{\circ} \mathrm{C}$ in a refrigerator for testing. A soil DNA kit (DNeasy Power Soil DNA Isolation Kit 12888-50, Mo Bio, USA) was used to extract DNA from microbial samples according to the instructions. The qualified DNA was amplified by PCR with 27F (5'-AGAGTTTGATCCTGGCTCAG-3') and 533R (5'TTACCGCGGCTGCTGGCAC-3') primers. After amplification, agarose gel electrophoresis, purification, and quantitative mixing were performed. Shanghai Meiji biomedical science and Technology Co., Ltd. was entrusted to complete the subsequent sequencing of the microorganisms. Finally, the gene sequence was compared in the GenBank to analyze the diversity of samples (Ma et al., 2019).

\section{Results and discussion}

\subsection{Nitrogen removal performance}

The EGSB reactor was started with anammox granular sludge. The nitrogen removal performance of the whole operation stage of the reactor is shown in Figure 2. The concentrations of $\mathrm{NH}_{4}^{+}-\mathrm{N}$ and $\mathrm{NO}_{2}{ }^{-}-\mathrm{N}$ on the first and second day were 63.85 and $60.68 \mathrm{mg} \mathrm{L}^{-1}$ respectively, and the hydraulic retention time (HRT) was $5 \mathrm{~h}$. However, in the remaining 3-22 days, the HRT of the reactor was 4 hours. The concentrations of $\mathrm{NH}_{4}{ }^{+}-\mathrm{N}, \mathrm{NO}_{2}{ }^{-}-\mathrm{N}$, and $\mathrm{TN}$ were 16.45, 0.27 , and $29.99 \mathrm{mg} \mathrm{L}^{-1}$, respectively. The removal rates of $\mathrm{NH}_{4}{ }^{+}-\mathrm{N}, \mathrm{NO}_{2}{ }^{-}-\mathrm{N}$, and TN were $79.08 \%, 99.60 \%$, and $78.04 \%$, respectively. The influent $\mathrm{pH}$ was 7.25 , and the effluent $\mathrm{pH}$ was 7.42. These phenomena indicate that the inoculated anammox bacteria have certain activity, but the volume load rate of TN (NLR) was only $0.61 \mathrm{~kg} \mathrm{~m}^{-3} \mathrm{~d}^{-1}$, which is still relatively low.

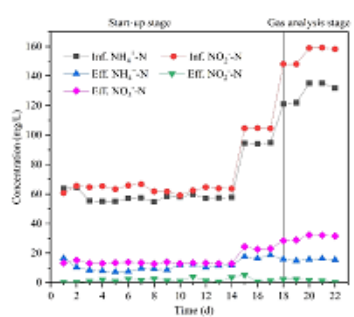

(a)

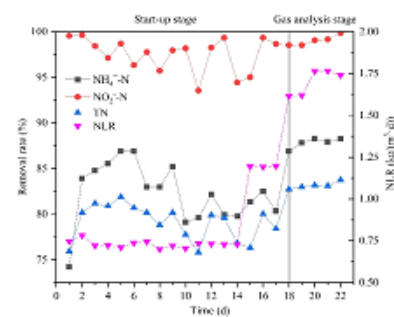

(b)
Figure 2. Nitrogen removal performance during reactor operation

(Where (a) shows the concentration of influent water and effluent water of the reactor, and (b) is the NLR and nitrogen removal of the reactor.)

To recover the activity of the reactor as soon as possible, the influent matrix concentration was gradually increase to improve the NLR of the reactor by fixing the HRT. The average concentrations of $\mathrm{NH}_{4}{ }^{+}-\mathrm{N}$ and $\mathrm{NO}_{2}{ }^{-} \mathrm{N}$ were 56.94 $\mathrm{mg} \mathrm{L}^{-1}$ and $63.58 \mathrm{mg} \mathrm{L}^{-1}$, respectively, from the $3^{\text {rd }}$ through the $14^{\text {th }}$ day. The average concentrations of $\mathrm{NH}_{4}{ }^{+}-\mathrm{N}, \mathrm{NO}_{2}{ }^{-} \mathrm{N}$, and TN in the effluent were then 9.70, 1.80, and $24.74 \mathrm{mg}$
$\mathrm{L}^{-1}$, respectively. The average removal rates of $\mathrm{NH}_{4}{ }^{+}-\mathrm{N}$, $\mathrm{NO}_{2}{ }^{-} \mathrm{N}$, and TN were $83.00 \%, 97.15 \%$, and $79.47 \%$, respectively. The activity of anammox was improved.

The concentrations of $\mathrm{NH}_{4}{ }^{+}-\mathrm{N}$ and $\mathrm{NO}_{2}{ }^{-}-\mathrm{N}$ in the influent were increased to $94.43 \mathrm{mg} \mathrm{L}^{-1}$ and $104.58 \mathrm{mg} \mathrm{L}^{-1}$, respectively, from the $15^{\text {th }}$ through the $17^{\text {th }}$ day. The average concentrations of $\mathrm{NH}_{4}^{+}-\mathrm{N}, \mathrm{NO}_{2}^{-}-\mathrm{N}$, and $\mathrm{TN}$ in the effluent were $17.57,2.43$, and $43.29 \mathrm{mg} \mathrm{L}^{-1}$, respectively. The average removal rates of $\mathrm{NH}_{4}{ }^{+}-\mathrm{N}, \mathrm{NO}_{2}{ }^{-}-\mathrm{N}$, and TN were $81.40 \%, 97.68 \%$, and $78.25 \%$, respectively. NLR increased from $0.72 \mathrm{~kg} \mathrm{~m}^{-3} \mathrm{~d}^{-1}$ to $1.19 \mathrm{~kg} \mathrm{~m}^{-3} \mathrm{~d}^{-1}$. The $\mathrm{pH}$ of the effluent was then 7.90. Some studies have shown that when the $\mathrm{pH}$ value of effluent is $7.5-8.3$, the activity of anammox is at a high level (Schalk et al., 2000). In addition, less gas was collected in the reactor on the first day, but a large amount of gas appeared in the reactor after 17 days. Currently, the color of an anammox granular sludge was redder. Therefore, we determined that the anammox reaction was successfully started at 17 days. The experiment was continued for five more days to analyze the gas change after the reactor was started successfully.

Therefore, after the NLR reached $1.19 \mathrm{~kg} \mathrm{~m}^{-3} \mathrm{~d}^{-1}$ on the 17 th day, the ratio of effluent circulating water flow to influent water flow was strictly controlled to be $2: 1$, and a gas analysis experiment was prepared. The concentrations of $\mathrm{NH}_{4}^{+}-\mathrm{N}$ and $\mathrm{NO}_{2}^{-}-\mathrm{N}$ in the influent water of the reactor from the $18^{\text {th }}$ to the $22^{\text {nd }}$ day were 128.962 and $154.494 \mathrm{mg}$ $\mathrm{L}^{-1}$, respectively. The $\mathrm{NH}_{4}{ }^{+}-\mathrm{N}$ concentration in the effluent was $15.67 \mathrm{mg} \mathrm{L}^{-1}$, and the average removal rate was $87.83 \%$. The concentration of $\mathrm{NO}_{2}{ }^{-} \mathrm{N}$ in the effluent was $1.472 \mathrm{mg} \mathrm{L}^{-1}$, and the removal rate was $99.04 \%$. The concentration of $\mathrm{NO}_{3}{ }^{-}-\mathrm{N}$ was $30.59 \mathrm{mg} \mathrm{L}^{-1}$, the average removal rate of $\mathrm{TN}$ was $83.15 \%$, the $\mathrm{pH}$ of effluent was stable at approximately 7.8 , which is significantly higher than that of the influent, and the NLR was stable at approximately $1.70 \mathrm{~kg} \mathrm{~m}^{-3} \mathrm{~d}^{-1}$. Combined with Figure 2, it can be seen that the reactor in this stage operates stably and has high nitrogen removal efficiency, which meets our requirements for gas analysis.

\subsection{Change of stoichiometric number during reactor operation}

According to the theory of anammox, the molar ratio of $\mathrm{NH}_{4}{ }^{+}-\mathrm{N}, \mathrm{NO}_{2}{ }^{-}-\mathrm{N}$, and $\mathrm{NO}_{3}{ }^{-}-\mathrm{N}$ is 1:1.32:0.26 (Van de Graaf et al., 1996). However, the molar ratios of $\mathrm{NH}_{4}{ }^{-}-\mathrm{N}, \mathrm{NO}_{2}{ }^{-}-\mathrm{N}$, and $\mathrm{NO}_{3}{ }^{-}-\mathrm{N}$ reported by various researchers are different. Strous $\mathrm{M}$ et al. (1999) observed that the ratio of $\mathrm{NO}_{2}^{-}-\mathrm{N}$ to $\mathrm{NH}_{4}{ }^{+}-\mathrm{N}$ removed by a sequencing batch reactor was 2:1. Generally speaking, the difference in the operating conditions and the structure of the bacterial community is an important reason for the difference of the stoichiometric number ratio. During the whole running period of this experiment, the average ratio of $\mathrm{NH}_{4}{ }^{+}-\mathrm{N}$, $\mathrm{NO}_{2}{ }^{-}-\mathrm{N}$, and $\mathrm{NO}_{3}{ }^{-}-\mathrm{N}$ was $1: 1.31: 0.28$. It's very close to the theoretical value. 


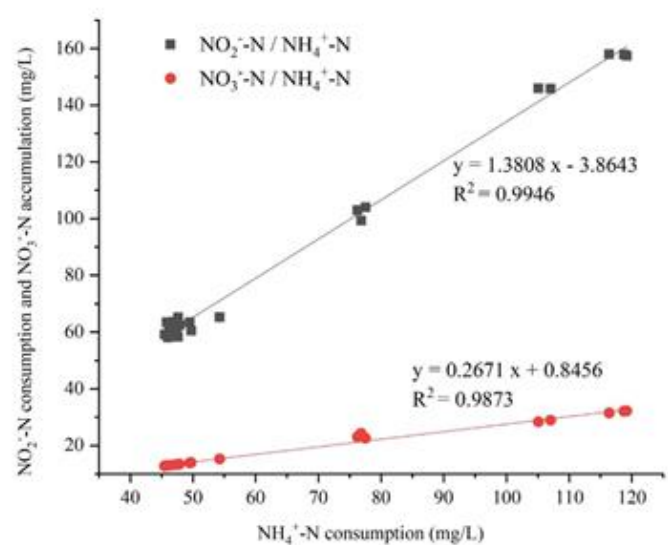

Figure 3. Fitting of stoichiometric number changes during reactor operation

With the operation of the reactor, anammox granular sludge coated with $\mathrm{AC}$ was gradually formed from the $3^{\text {rd }}$ to $14^{\text {th }}$ day. The ratio of generated $\mathrm{NH}_{4}{ }^{+}-\mathrm{N}, \mathrm{NO}_{2}{ }^{-}-\mathrm{N}$, and $\mathrm{NO}_{3}{ }^{-}-\mathrm{N}$ was $1: 1.31: 0.28$. From the $15^{\text {th }}$ to $17^{\text {th }}$ day, the ratio of $\mathrm{NH}_{4}{ }^{+}-\mathrm{N}, \mathrm{NO}_{2}{ }^{-} \mathrm{N}$, and $\mathrm{NO}_{3}{ }^{-}-\mathrm{N}$ was 1:1.33:0.30, which was close to $1: 1.32: 0.26$, and the removal rate of total nitrogen was higher. At this time, the operation of the reactor is stable, indicating that the anammox reactor had been successfully started. The ratio of the $\mathrm{NH}_{4}{ }^{+}-\mathrm{N}$ and $\mathrm{NO}_{2}{ }^{-}-\mathrm{N}$ removed to the $\mathrm{NO}_{3}{ }^{-} \mathrm{N}$ generated was $1: 1.35: 0.27$ on the $18^{\text {th }}$ to $22^{\text {nd }}$ day of gas analysis. The linear fitting curve of the change of the stoichiometric number during the operation of the whole reactor is shown in Figure 3. The relationship between $\mathrm{NO}_{2}{ }^{-}-\mathrm{N} / \mathrm{NH}_{4}{ }^{+}-\mathrm{N}$ and $\mathrm{NO}_{3}{ }^{-}-\mathrm{N} / \mathrm{NH}_{4}{ }^{+}-\mathrm{N}$ is linear. The equation of $\mathrm{NO}_{2}{ }^{-}-\mathrm{N} / \mathrm{NH}_{4}{ }^{+}-\mathrm{N}$ obtained from the fit is $y=1.3808 x-3.8643$, and the slope is 1.38. This shows that the $\mathrm{NO}_{2}{ }^{-}-\mathrm{N} / \mathrm{NH}_{4}{ }^{-}-\mathrm{N}$ removed during the whole operation period was approximately 1.38 . The correlation coefficient $\mathrm{R}^{2}=0.9946$; therefore, the reliability of the curve fitting is high. The $\mathrm{NO}_{3}{ }^{-}-\mathrm{N} / \mathrm{NH}_{4}{ }^{+}-\mathrm{N}$ ratio equation is $y=0.2671 x+0.8456$, and the slope is 0.27 . This shows that the $\mathrm{NO}_{3}{ }^{-}-\mathrm{N} / \mathrm{NH}_{4}{ }^{+}-\mathrm{N}$ produced during the whole operation period is approximately 0.27 , the correlation coefficient $R^{2}=0.9873$, and the reliability of linear fitting is good. Therefore, the fitting ratio of the $\mathrm{NO}_{2}{ }^{-}-\mathrm{N} / \mathrm{NH}_{4}{ }^{+}-\mathrm{N}$ removed and the $\mathrm{NO}_{3}{ }^{-}-\mathrm{N} / \mathrm{NH}_{4}{ }^{+}-\mathrm{N}$ generated during the operation of the whole reactor is 1:1.38:0.27, which is close to $1: 1.32: 0.26$. This indicates that the potential $\mathrm{NH}_{4}{ }^{+}-\mathrm{N}$ : $\mathrm{NO}_{2}{ }^{-} \mathrm{N}$ : $\mathrm{NO}_{3}{ }^{-}-\mathrm{N}$ ratio is 1:1.38:0.27 during the whole operation period of our reactor for 22 days. This may be related to the presence of a small amount of shortcut nitrifying bacteria in the reactor, which transforms a small part of $\mathrm{NH}_{4}{ }^{+}-\mathrm{N}$ into $\mathrm{NO}_{2}^{-}-\mathrm{N}$, and the presence of Nitrosomonas in the "3.5 Microbial diversity analysis" section also verifies this problem. All these values indicate that the EGSB reactor had been started successfully at the $17^{\text {th }}$. However, in our previous study, it took 34 days to start the EGSB reactor using anammox bacteria stored at nearly 2 years (Zhang et al., 2014). Therefore, our experiment confirmed that the start-up time of EGSB reactor was shortened after adding activated carbon.
The comparison of the start-up performance of different Anammox processes was summarized in Table 2 . In most cases, a lengthy hydraulic retention time (HRT) was adopted in order to retain enough sludge in the Anammox reactors. In this study, HRT was shortened at $4 \mathrm{~h}$. Compared with other seed sludge, seeding granular sludge supported on AC could decrease the start-up time of the Anammox process greatly (from 34-101 days to two weeks). Furthermore, only a little floating sludge was observed during the study period. It might be contributed by activated carbon, which was employed as seed sludge, and then the settling ability of biomass could be enhanced.

\subsection{Gas collection and analysis}

After the activity of the reactor returned to stable operation, the gas generation of the reactor was investigated. The gas production rate and gas collection of the reactor were analyzed and monitored for 5 days (days 18 to 22). $\mathrm{N}_{2} \mathrm{O}, \mathrm{CO}_{2}$ and $\mathrm{N}_{2}$ may be produced during anammox reaction. Heterotrophic denitrification is the main biological mechanism of $\mathrm{N}_{2} \mathrm{O}$ emission in anammox granules (Okabe et al., 2011). After repeated experiments, the retention time of $\mathrm{N}_{2} \mathrm{O}$ was approximately $2.1 \mathrm{~min}$, and that of $\mathrm{CO}_{2}$ was approximately $1.6 \mathrm{~min}$. The collected gas samples from the EGSB reactor were tested, and the chromatogram is shown in Figure 4. The peak value of $\mathrm{N}_{2} \mathrm{O}$ and $\mathrm{CO}_{2}$ appeared at the specified time. The peak area of the second peak in the figure is the largest. According to the substances and proportion generated in the anammox reaction, it is speculated that the gas is likely to be $\mathrm{N}_{2}$. The fifth peak in Figure 3 has a retention time of $7.582 \mathrm{~min}$, which may be $\mathrm{CH}_{4}$ or other gases. However, measurements of $\mathrm{N}_{2}, \mathrm{CH}_{4}$, and other standard gases should be made to prove detection.

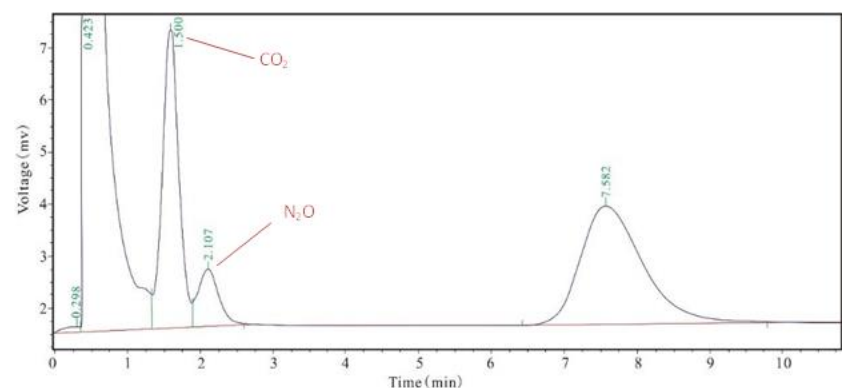

Figure 4. Chromatograms of gas sample

After calculation, the average gas production rate of the reactor is $1.11 \mathrm{~L} \mathrm{~h}^{-1}$, and the average content of $\mathrm{N}_{2} \mathrm{O}$ and $\mathrm{CO}_{2}$ is $0.8 \%$ and $0.02 \%$, respectively. According to our previous research, there is a significant correlation between $\mathrm{N}_{2} \mathrm{O}$ production and $\mathrm{NH}_{4}^{+}-\mathrm{N}$ concentration in the influent. When the concentration of $\mathrm{NH}_{4}{ }^{+}-\mathrm{N}$ in the influent was increased from $36 \mathrm{mg} \mathrm{L}^{-1}$ to $57 \mathrm{mg} \mathrm{L}^{-1}, \mathrm{~N}_{2} \mathrm{O}$ also increased from $0.65 \%$ to $1.4 \%$ (Jin et al., 2016). The concentration of the influent $\mathrm{NH}_{4}{ }^{+}-\mathrm{N}$ was $128.96 \mathrm{mg} \mathrm{L}^{-1}$, and $\mathrm{N}_{2} \mathrm{O}$ production was only $0.8 \%$. This may be related to the NLR in this experiment. The NLR was $1.80 \mathrm{~kg} \mathrm{~m}^{-3} \mathrm{~d}^{-1}$ in this study stage, which was higher than that in Jin et al. (2016). Therefore, by controlling the concentration of $\mathrm{NH}_{4}{ }^{+}-\mathrm{N}$ in the influent water, increasing the NLR, 
strengthening niche competition, and limiting the growth and activity of Nitrosomonas, $\mathrm{N}_{2} \mathrm{O}$ production can be effectively reduced.

\subsection{Sludge form}

When the reactor was initially started, the color of the sludge was mainly black with $\mathrm{AC}$ and a small number of red anammox bacteria. After 17 days of operation, the color of the sludge in the reactor changed to brick red, which was dominated by anammox. Anammox bacteria display a unique red color because they contain a series of heme $C$ proteins (cytochrome c) (Kartal and Keltjens, 2016). Therefore, the appearance color can be used as a rough assessment of anammox activity. After a period of culture, anammox microorganisms are adsorbed and bound together under the action of extracellular polymeric substances (EPS), forming granular sludge tightly wrapped with AC (Jia et al., 2017). The size of the AC at the beginning of the experiment was 3-4 mm. With the operation of the reactor, anammox bacteria attached to the $A C$, which made the AC size increase to 4-5 $\mathrm{mm}$. In addition, according to the change of the stoichiometric number of each reaction matrix and the high removal rate, the reactor is stable at this time and the activity of anammox granular sludge is good.

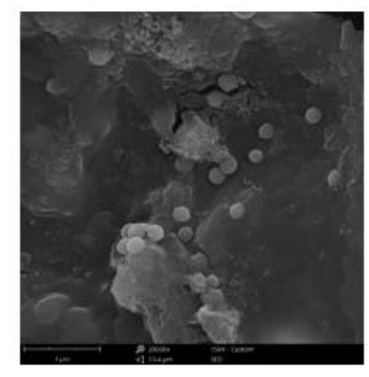

(a)

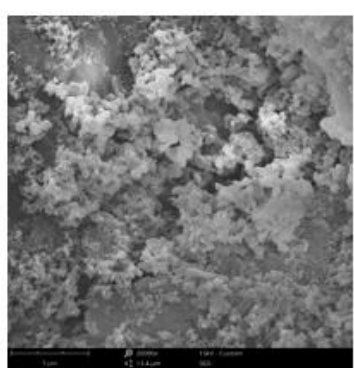

(b)
Figure 5. SEM image of granular sludge in the reactor

(Where (a) is the initial sludge in day 1 and (b) is the sludge when the reactor is successfully started in day 17.$)$

\subsection{Scanning electron microscope}

After pretreatment of the initial and later sludge, an SEM experiment was carried out, and the image is shown in Figure 5, (a) and (b). There are more viscous substances and globular bacteria scattered on the surface of the initially inoculated sludge. It has been reported that typical anammox bacteria are mostly gram-negative spherical bacteria with a diameter of approximately $1 \mu \mathrm{m}$ (Van Niftrik et al., 2008). Therefore, we can speculate that the spherical bacteria observed in the figure are anammox bacteria. With the successful start-up of the reactor, the amount of anammox granular sludge increased. The microorganisms in the anammox sludge gathered intensively, and there were a lot of spherical bacteria on the surface of the granular sludge. Currently, the anammox activity of the EGSB reactor is very good. The reactor has high acid consumption, low DO concentration and red sludge.

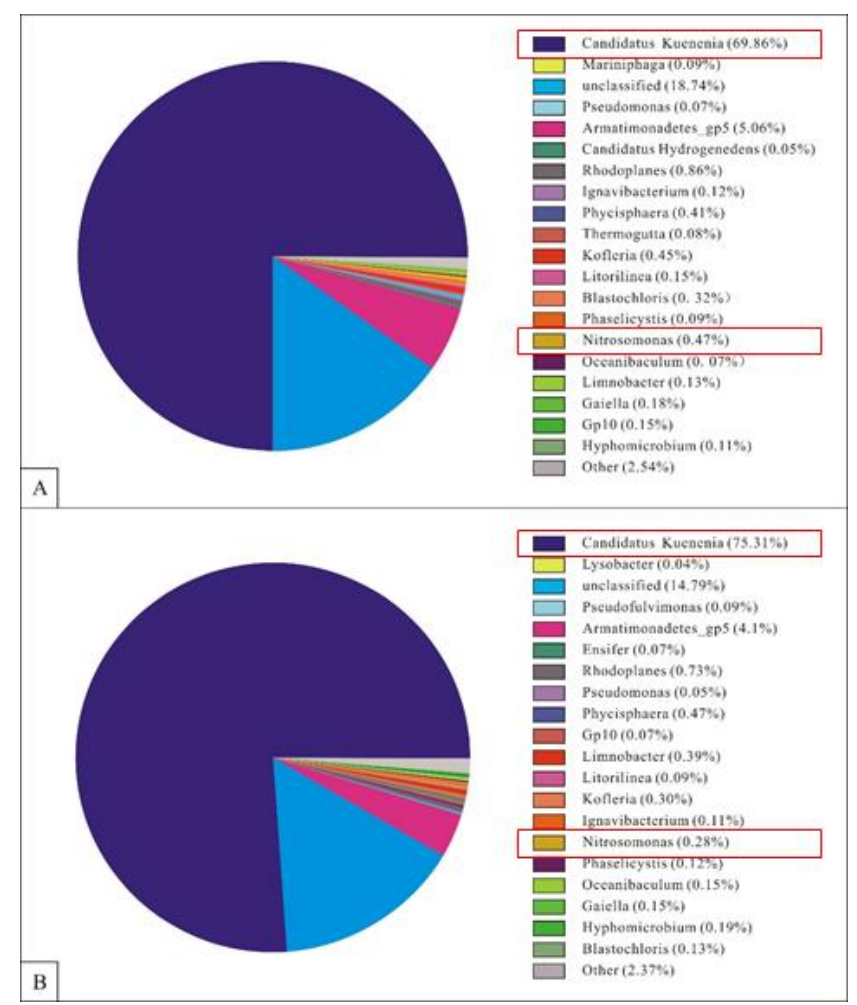

Figure 6. Genus level abundance of anammox granular sludge

\subsection{Microbial diversity analysis}

The stored granular sludge of anammox was studied by microbiological analysis. The sludge sample at the beginning of the reactor run is called sample $A$, and sample $B$ is sludge 17 days after beginning the reactor. After DNA extraction and PCR experiments, the diversity of sludge samples was analyzed. The Shannon index and Simpson index of sample a and sample B were 1.80, 1.81 and 0.53 , 0.52 , respectively. The coverage rate of both samples is 0.97 , which indicates that the probability of undetected sequences was low and the authenticity of samples was high. Figure 6 is a 2D pie chart of the abundance of a single sample at the level of the genus. The main functional dominant microorganism of the anammox granular sludge with certain activity used when we started the reactor belongs to Candidatus Kuenenia. With the operation of the reactor and the increase of the time inflow load, the microbial community gradually changed. At the end of the reactor operation, the proportion of Candidatus Kuenenia increased by $5.45 \%$. Although the increase of anammox bacteria is not high, the activity of anammox has been greatly improved from the perspective of denitrification rate and NLR. At the same time, Nitrosomonas was found in two sludge samples. It can also be analyzed from the figure that with the operation of the reactor, Nitrosomonas have been eliminated in a few regions due to the anaerobic environment, and their proportion is $0.19 \%$ less than that at the beginning. These results show that our EGSB reactor started successfully.

The composition of the functional genes in the samples was inferred from the species composition obtained by $16 \mathrm{~S}$ sequencing, and the functional genes in the samples were analyzed. Figure 6 shows the functional classification and 
distribution of genes in the initial sample, and the sequence is from large to small according to the overall abundance. We can see from Figure 7 that there is a large number of replication and recombination genes in the initial samples, which is the main mechanism of generating new genetic material in the process of molecular evolution. In addition, there are many genes for energy production and conversion and cell wall and cell membrane formation, which can promote the rapid propagation of anammox. Most importantly, there are many genes related to coenzyme transport and metabolism, inorganic ion transport and metabolism, and lipid transport and metabolism. These genes are very helpful for anammox bacteria to remove inorganic nitrogen. There are many coenzymes involved in the transformation in the nitrogen removal mechanism of anammox (Kartal et al., 2011). First, $\mathrm{NO}_{2}{ }^{-}$is reduced to $\mathrm{NO}$ or hydroxylamine by nitrite reductase (Nir). Then, $\mathrm{NO}$ is converted into $\mathrm{NH}_{2} \mathrm{OH}$ by hydroxylamine oxidase ( $\mathrm{HAO}$ ), after which $\mathrm{NH}_{2} \mathrm{OH}$ and $\mathrm{NH}_{4}{ }^{+}$ are condensed into $\mathrm{N}_{2} \mathrm{H}_{4}$ by hydrazine hydrolase. Finally, hydrazine oxidase $(\mathrm{HZO})$ further catalyzes the oxidation of $\mathrm{N}_{2} \mathrm{H}_{4}$ to $\mathrm{N}_{2}$ and $\mathrm{H}_{2} \mathrm{O}$, while nitrite oxidase (Nar) oxidizes $\mathrm{NO}_{2}{ }^{-}$to $\mathrm{NO}_{3}{ }^{-}$. Due to the unique structure of anammox bacteria, it can be used in a variety of wastewater treatment environments.

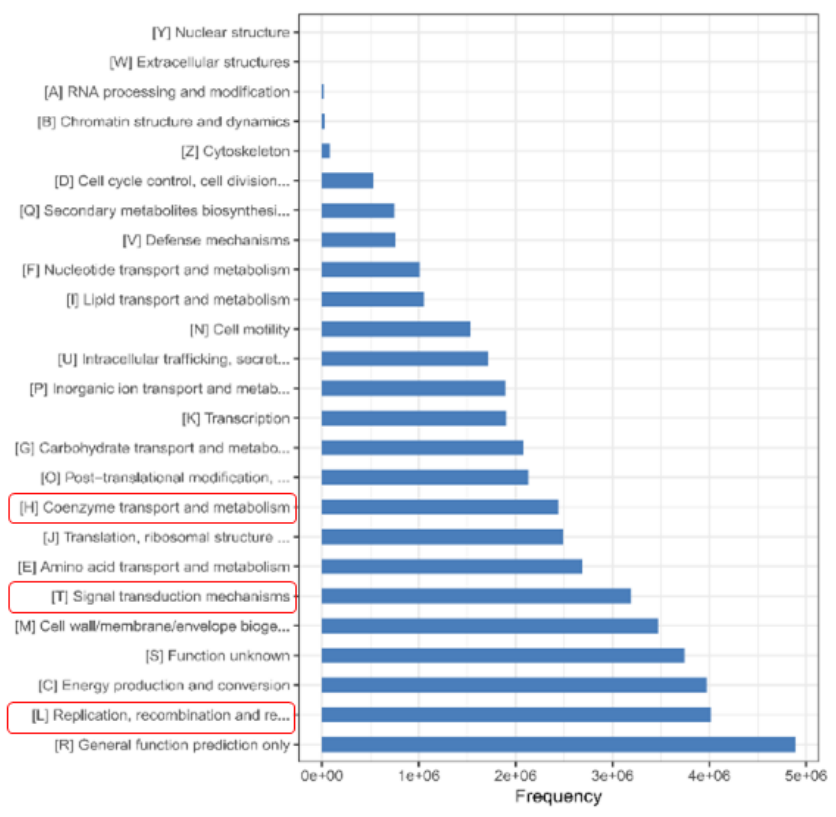

Figure 7. Functional classification and distribution of genes

\section{Conclusions}

In this experiment, the start-up time of an EGSB reactor inoculated with granular sludge supported on $A C$ as the carrier was substantially shortened by combining the method of gradually increasing the matrix concentration and fixing the HRT. It took only 17 days to start the reactor successfully. The NLR was $1.19 \mathrm{~kg} \mathrm{~m}^{-3} \mathrm{~d}^{-1}$, and the ratio of $\mathrm{NH}_{4}{ }^{+}-\mathrm{N}: \quad \mathrm{NO}_{2}{ }^{-}-\mathrm{N}: \quad \mathrm{NO}_{3}{ }^{-}-\mathrm{N}$ stoichiometry number was $1: 1.33: 0.30$, very close to $1: 1.32: 0.26$. The NLR of the reactor can be further improved. It increased to $1.70 \mathrm{~kg} \mathrm{~m}^{-3}$ $\mathrm{d}^{-1}$ on days 18-22, and the average content of $\mathrm{N}_{2} \mathrm{O}$ and $\mathrm{CO}_{2}$ was less than $0.8 \%$ and $0.02 \%$, respectively. As can be seen from the gas chromatogram in Figure 4, our reaction will produce four gases. However, in this experiment, we only calculated the production of these two gases. We'll test the other two gases later. Based on the rapid start-up of anammox reactor in this experiment, we will study the reasons that affect the proliferation of anammox sludge. Meanwhile this shows that the operation mode of our reactor is very effective for the quick start of the reactor, and the granular sludge bacteria supported on AC can also show great potential in shock load resistance. Additionally, the analysis of microorganisms showed that the spherical bacteria in the reactor were mainly Candidatus Kuenenia. The reactor inoculated with acclimated anammox sludge started quickly, so it is a good strategy to collect anammox sludge from an anammox reactor for production. This study provides a reference for the rapid start-up of anammox granular sludge for engineering applications.

\section{Acknowledgement}

Thanks to the special support of the National Natural Science Foundation of China [grant numbers 51668013, 51638006]; Guangxi Natural Science Foundation [grant numbers 2019GXNSFFA245017]; Special Funding for Guangxi "BaGui Scholar" Construction Projects.

\section{References}

Basta A.H., Lotfy V.F., Hasanin M.S., Trens P. and El-Saied H. (2019), Efficient treatment of rice byproducts for preparing high-performance activated carbons, Journal of Cleaner Production, 207, 284-295.

Jetten M.S.M., Strous M., Pas-Schoonen K.T.d., Schalk J., Dongen U.G.J.M., Graaf A.A.d., Logemann S., Muyzer G., Loosdrecht M.C.M. and Kuenena J.G. (1998), The anaerobic oxidation of ammonium, FEMS Microbiology Reviews, 22, 421-437.

Jia F., Yang Q., Liu X.H., Li X., Li B., Zhang L. and Peng Y. (2017), Stratification of Extracellular Polymeric Substances (EPS) for Aggregated Anammox Microorganisms, Environmental Science \& Technology, $\mathbf{5 1 .}$

Jin P., Li B., Mu D., Li X. and Peng Y. (2019), High-efficient nitrogen removal from municipal wastewater via two-stage nitritation/anammox process: Long-term stability assessment and mechanism analysis, Bioresource Technology, 271, 150158.

Jin Y., Wang D. and Zhang W. (2016), Effects of substrates on $\mathrm{N}_{2} \mathrm{O}$ emissions in an anaerobic ammonium oxidation (anammox) reactor, Springer Plus, 5, 741-752.

Kartal B. and Keltjens J. (2016), Anammox biochemistry: a tale of heme c proteins, Trends in Biochemical Sciences, 41.

Kartal B., Maalcke W., Almeida N., Cirpus I., Gloerich J., Geerts W., Op den Camp H., Harhangi H., Janssen-Megens E., Francoijs K.-J., Stunnenberg H., Keltjens J., Jetten M. and Strous M. (2011), Molecular mechanism of anaerobic ammonium oxidation, Nature, 479, 127-130.

Liu X., Jin Y. and Zhang W. (2020), Effect of nitrite concentration on the growth and microbial diversity of anaerobic ammonia oxidation (anammox) sludge, 54-62. 
Liu X., Wang H., Li H., Jin Y. and Zhang W. (2019), Carbon sequestration pathway of inorganic carbon in partial nitrification sludge, Bioresource Technology, 293, 122101.

Ma X., Jin Y. and Zhang W. (2019), Effects of $\mathrm{Ca}^{2+}$ Concentration on Anaerobic Ammonium Oxidation Reactor Microbial Community Structure, Water, 11, 1341.

Miao Y., Zhang J., Peng Y. and Wang S. (2020), An improved startup strategy for mainstream anammox process through inoculating ordinary nitrification sludge and a small amount of anammox sludge, Journal of Hazardous Materials, 384, 121325.

Mulder A., van de Graaf A.A., Robertson L.A. and Kuenen J.G. (1995), Anaerobic ammonium oxidation discovered in a denitrifying fluidized bed reactor, FEMS Microbiology Ecology, 16, 177--83.

Okabe S., Oshiki M., Takahashi Y. and Satoh H. (2011), $\mathrm{N}_{2} \mathrm{O}$ emission from a partial nitrification-anammox process and identification of a key biological process of $\mathrm{N}_{2} \mathrm{O}$ emission from anammox granules, Water Research, 45, 64616470.

Schalk J., Vries S., Kuenen J.G. and Jetten M. (2000), Involvement of a Novel hydroxylamine oxidoreductase in anaerobic ammonium oxidation ${ }^{\dagger}$, Biochemistry, 39, 5405-5412.

Strous M., Heijnen J.J., Kuenen J.G. and Jetten M.S.M. (1998), The sequencing batch reactor as a powerful tool for the study of slowly growing anaerobic ammonium-oxidizing microorganisms, Applied Microbiology and Biotechnology, 50, 589-596.

Strous M., Kuenen J.G. and Jetten M.S.M. (1999), Key physiology of anaerobic ammonium oxidation, Applied and Environmental Microbiology, 65, 3248-3250.

Tomar S., Gupta S. and Mishra B. (2015), Performance evaluation of anammox hybrid reactor seeded with mixed inoculum sludge, Environmental Technology, 37, 1-34.

Tang C.-J., Zheng P., Chai L.-Y. and Min X.-B. (2013), Characterization and quantification of anammox start-up in UASB reactors seeded with conventional activated sludge, International Biodeterioration \& Biodegradation, 82, 141148.

Van de Graaf A.A., Bruijn P., Robertson L., Jetten M. and Kuenen J.G. (1996), Autotrophic growth of anaerobic ammoniumoxidizing micro-organisms in a fluidized bed reactor, Microbiology, 142, 2187-2196.

Van Niftrik L., Geerts W.J.C., van Donselaar E.G., Humbel B.M., Yakushevska A., Verkleij A.J., Jetten M.S.M. and Strous M. (2008), Combined structural and chemical analysis of the anammoxosome: A membrane-bounded intracytoplasmic compartment in anammox bacteria, Journal of Structural Biology, 161, 401-410.

Wang Q., Wang Y., Lin J., Tang R., Wang W., Zhan X. and Hu Z.-H. (2018), Selection of seeding strategy for fast start-up of Anammox process with low concentration of Anammox sludge inoculum, Bioresource Technology, 268, 638-647.

Wen R., Jin Y. and Zhang W. (2020), Application of the anammox in China-a review, International Journal of Environmental Research and Public Health, 17, 1090.

Wu P., Zhang X., Wang X., Wang C., Faustin F. and Liu W. (2020), Characterization of the start-up of single and two-stage Anammox processes with real low-strength wastewater treatment, Chemosphere, 245, 125572.
Zhang W., Wang H., D.R.J. and Jin Y. (2015), Granular activated carbon as nucleus for formation of anammox granules in an expanded granular-sludge-bed reactor, Global NEST Journal, 17, 508-514.

Zhang W., Zhang Y., Li L., Zhong X. and Jin Y. (2014), Fast start-up of expanded granular sludge bed (EGSB) reactor using stored Anammox sludge, Water Science Technology, 69, 1469-1474. 